\title{
The Discursive Negotiation of International Student Identities
}

\author{
Michael Haugh* \\ Griffith University, Australia
}

Research about identity has undergone a discursive turn in recent years, with a shift from conceptualizing identity as an essentialistic, pre-existing construct that drives social interaction, to a more fluid and hybrid construct that is constituted through discourse. As a result, a number of recent studies investigating the construction of international student identities have supposedly adhered to this latter, postmodernistinspired notion of identity in their analyses. However, upon closer examination, these studies appear to be premised upon the assumption that what international students say can be equated with their identities, without critical attention being paid to the way in which identities emerge as a conjoint construct through interaction. In this paper, it is argued that identities are invariably jointly constructed by participants through discourse, even in interviews and focus groups where the researcher is ostensibly taking a neutral stance, and thus more attention needs to be paid to the ways in which identities are discursively negotiated through interaction.

Key words: Identity, international students, postmodernism, conversation analysis, interactional analysis

\footnotetext{
* School of Languages and Linguistics, Griffith University, Nathan, QLD 4111, Australia. Email: m.haugh@griffith.edu.au
} 


\section{Introduction}

International students have continued to be the focus of simplistic stereotyping in media discourse where they are frequently identified as one of the forces behind declining academic standards or as "cash cows" for cash-strapped universities in an increasingly competitive international education market. Devos (2003), for example, in a careful examination of the manner in which 'the international student' was constructed in media discourse in early 2001, found that international students were invariably constructed as a source of 'contempt' (for their perceived lack of adequate English language skills), yet paradoxically also as 'valuable' (in relieving the financial pressures facing Australian universities). Central to this characterization was the identification of international students in media discourse as 'the other', a construct that only exists in contrast to another construct, namely 'local students' (ibid., p. 164). An examination of more recent texts from the Australian media indicates that little has changed in the way in which the identities of international students are discursively constructed. The theme that international students do not have adequate English skills and thus are contributing to falling standards in Australian universities, for example, remains prominent (Fullerton, 2005; Hart and Edwards, 2007; Hills, 2005; Jopson \& Burke, 2005; Ingram, 2005; Macnamara, 2006, 2007; Morris, 2004).

In response to this fairly one-dimensional representation of international students in media discourse, the manner in which international students themselves construct their identities has become the focus of a number of studies in recent years. These studies have generally concentrated on eliciting the self-perceptions of international students through in-depth analyses of interview data (Dalglish \& Chan, 2005; East, 2001; Koehne, 2005, 2006; Leder \& Forgasz, 2004; Miller, 2000; Morita 2004). Yet while this research into the ways in which international students perceive themselves represents an important first step away from the essentialistic views of international students as constituting a 'homogenous group', these studies have often been premised on a somewhat uncritical view of the actual process by which identities are constructed through discourse. A number of studies appear to be premised upon the assumption that what international students say can be straightforwardly equated with their identities, without critical attention being paid to the contribution of the interviewer to the discursive construction of identities in such contexts (Dalglish \& Chan, 2005; East, 2001; Koehne, 2005, 2006). Even when other data collection methods are used, such as questionnaires (East, 2001; Sherry, Bhat, Beaver \& Ling 2004) or self-reporting of activities (Leder \& Forgasz, 2004; Morita, 2004), the researcher is assumed to be neutral to the extent that his or her viewpoint is not commented upon. In these analyses, then, the epistemological status of the contributions made by interviewer or other participants to the interaction and thus analysis is not made clear.

In this paper, it is first argued that this epistemological trap is symptomatic of the broader postmodern program, which arguably has not fully realized the promise of its theoretical insights in actual empirical studies of identity. It is then suggested that an approach to the analysis of identity grounded in insights from ethnomethodology and conversation analysis is better positioned to further our understanding of how identities are discursively constructed in research interviews. This interactional approach is then applied to an analysis of interview data from focus groups to emphasize how identities are jointly negotiated by participants. 


\section{The postmodern turn in identity research}

Identity has been conceptualized in research over the past thirty years as a placeholder for the social psychological processes underlying self-definition or self-interpretation (Simon, 2004), with a distinction being made between personal identity, or "a selffashioning, agentive, internal project of the self' (Benwell \& Stokoe, 2006, p. 17), and social/collective identity, or self-definition through "membership of, or identification with a particular group or groups (ibid., p. 24). Yet in spite of this move in modern identity research to conceptualise identity as intersubjective, identity itself has still inevitably been "theorized as pre-discursive, unified and essential" (ibid., p. 25) in such approaches.

In recent times, however, the study of identity has been greatly influenced by the postmodern view of the subject as being "unstable, in process and constituted in language" (Weedon, 1987, p. 64). While the term postmodernism itself is not easily defined, it serves as an umbrella term for a diverse range of perspectives grounded in a broadly constructionist perspective on the nature of (social) 'reality' (Berger \& Luckmann, 1966). However, postmodernism goes beyond this constructionist tenet in its particular interest in the "progressive deconstruction and dissolution of distinctions" (Crotty, 1998, p. 192), thereby leaving those theorizing about concepts such as identity with "nothing to do but continue to think with them - albeit now in their detotalized or deconstructed forms" (Hall, 1996, p. 1). Consequently, there has been little in the way of the development of a clear 'postmodern research methodology', as such a development is fundamentally antithetical to a perspective that focuses on the breaking of distinctions.

Koehne's $(2005,2006)$ recent work how on the multiple and often hybrid identities of international students are constructed through discourse by international students themselves is perhaps one exemplar of this postmodern turn in identity research. Drawing from postmodern work on identity by Hall (1996), Weedon (1987), Foucault (1979) and others, she argues that international student identities involve "a constant movement between flows and closures in relation to their subjectivity" (Koehne, 2005, p. 108), where 'flow' implies "the development of new ways of talking and thinking about oneself, the opening up of spaces in relation to subjectivity" (ibid., p. 109), while 'closure' implies "discursive practices that speak of people as same or different" (ibid., p. 110). International students, therefore, cannot be simply defined as 'the other' in opposition to local students, but need to be examined more carefully in their own right as agents who both reconstruct their own multiple subjectivities, as well as challenge the discursive positionings attributed to them by others (Koehne, 2006, pp. 247-248).

Yet while postmodern approaches to subjectivities, which claim they are "constituted in language", have resulted in more nuanced understandings of the identities of international students, the ways in which the interview data itself has been analysed in these studies is arguably problematic, as the interviewer's contribution to the discursive construction of international student identities is not adequately acknowledged. In an example taken from one such study, the researcher frames the interviewer's talk as simply a means of eliciting what international students say about themselves in constructing their identities as persons who are not valued as part of the Australian community.

Rather than being valued as an important element of a system that values a diversity of ways of being a student, diversity of learning styles and a multiplicity of voices and experiences, they found there was limited opportunity to express their knowledge and experience. (Koehne, 2006, p.247) 
Evidence for this analysis of the international students' identities was based, in part, on the following extract from one of the interviews, where $\mathrm{S}$ represents the student and $\mathrm{N}$ represents the interviewer.

1 S: $\quad$ Yes, we are supposed to fit in, but not them to come into with us.

2 N: Yes, but would you agree with that?

3 S: You struggle to fit in the culture.

$4 \mathrm{~N}: \quad$ Exactly...

5 S: Well you can't fit in $100 \%$ no...So then there is this way out. The culture will

6 come to you, even if you can't fit in $100 \%$ but at least $50 \%$ or $60 \%$.

(adapted from Koehne, 2006, p. 247)

In line 1, the student positions international students as being asked to fit in with local students without local students being asked to make similar adjusts. The interviewer interprets this as implying that the student does not agree with such positioning in line 2 , which is further developed by the student in line 3 when she responds that she is not able to meet those expectations. In line 4, the interviewer's response, "exactly", is indicative of her understanding of the student's utterance in line 1 as implying the student is not able to adapt to the perceived local culture, and also endorses this particular positioning in relation to the student's identity. The student then goes on to also ratify the interviewer's understanding apparent in lines 5-6, although she qualifies it somewhat in claiming she can only partially adapt. In examining this extract from the interview, then, it is apparent that the discursive construction of this student's identities, and the identities of international students in general as cultural outsiders through the use of plural pronouns we and us in line 1 by the student in this instance emerges through the reciprocal influence of each participant's understandings of each other's utterances in the course of this sequence. The interviewer's contribution is thus of fundamental importance to the emergence of the student's identity in this example. ${ }^{1}$

The way in which identities jointly emerge in such examples is not made apparent despite the theoretical insights into the discursive construction of identity postmodern theories of discourse provide. This kind of analysis is perhaps a direct consequence of the relative neglect of methodology in the postmodern program on identity, as recently argued by Benwell and Stokoe (2006).

most of the 'grand' theories of discourse...engage in only the slenderest of ways with actual situated examples of language use, neglecting both linguistic detail and empirical evidence: how exactly are identities discursively produced or performed? What is the process or mechanism by which the individual speaker takes up positions in discourse to which they have been summoned? (Benwell \& Stokoe, 2006, p. 35, original emphasis)

This is not to say that interviews, focus groups or other such qualitative methodologies per se are inherently flawed, as a strong research tradition has evolved around such approaches (Barbour \& Kitzinger, 1999; Ho, 2006; Miller \& Glassner, 2004; Morgan, 1996, 1997; Wilkinson, 2004). But as Kitzinger (1994) and Wilkinson (2004, p. 184) argue, it is important to acknowledge the interactional nature of such data in any analysis of the identities arising in such contexts.

\section{Interactional approaches to identity}

Recently emerging work on identity in discourse has advocated investigating how identity is "actively, ongoingly, dynamically constituted in discourse", or more specifically, how "people perform, ascribe and resist identity, and how what it means

\footnotetext{
${ }^{1}$ See Koehne (2005, p. 116) for a similar example involving prompting by the interviewer of the student to identify with a "third culture", which is seen as evidence for the hybrid nature of international student identities.
} 
to 'have an identity' is produced in talk and texts of all kinds" (Benwell \& Stokoe, 2006 , p. 4). In this approach, then, identity is broadly defined as a process, not as a given or product.

Identity is a process that (1) takes place in concrete and specific interactional occasions, (2) yields constellations of identities instead of individual, monolithic constructs, (3) does not simply emanate from the individual, but results from processes of negotiation, and entextualization...that are eminently social, and (4) entails "discursive work." (De Fina, Schiffrin \& Bamberg, 2006, p. 2)

In establishing empirical evidence for such an interactional perspective on identity, it has been suggested that ethnomethodology and conversation analysis can provide a solid foundation for analyses of identities emerging through research interviews and focus groups (Benwell \& Stokoe, 2006, p. 35; Johnson, 2006, p. 231; Wilkinson, 2004, p.188).

While research into identity has not been a primary focus of conversation analysts, Schegloff (1996, p. 4) argues that an analysis of 'talk' must lie at the core of any analysis of social phenomena, including "who we are to one another" (Drew, 2005, p. 74). ${ }^{2}$ Crucial to an interactional approach to identity, then, is the understanding that identity has "to be treated as inherently locally produced, incrementally developed, and, by extension, as transformable at any moment" (Heritage, 2005, p. 111). In other words, conversation analysis "charts the identity work of shifting selves, contingent on the unfolding demands of talk's sequential environment" (Antaki, Condor \& Levine 1996, p. 477). However, in undertaking such an analysis, it is considered imperative to establish that the attributed 'identity work' is 'demonstrably relevant to the participants" (Schegloff, 1992, p. 192) by linking those identity claims to specific actions in the discourse (Antaki \& Widdicombe, 1998, p. 4; Schegloff, 1991, p. 50).

While a number of closely aligned interactional approaches to identity have been developed as ethnomethodology and conversation analysis have influenced researchers working on identity, it is suggested in this paper that the communication theory of identity (Hecht, 1993; Hecht, Warren, Jung \& Kreiger, 2005; Jung \& Hecht, $2004)$ is a potentially useful approach in which to frame an interactional analysis of identity.

\section{A Communicative View of Identity}

The communication theory of identity (Hecht, 1993; Hecht, Warren, Jung \& Kreiger, 2005; Jung \& Hecht, 2004) is premised on the assumption that identities do not exist $a$ priori or independently of discourse, but rather are discursively accomplished through social interaction. Importantly, while it draws from the concept and tools of conversation analysis in placing importance on participant understandings to establish the procedural relevance of the analysis, it also retains an important place for theorizing by the analyst. ${ }^{3}$ According to the communication theory of identity (CTI), the discursive accomplishment of identities involves four interpenetrating layers: personal (identities as an individual's self-concepts or self-images), enacted (identities as performed or expressed in communication), relational (identities as jointly negotiated through communication, including identifying oneself through one's

\footnotetext{
${ }^{2}$ Thus, while other aspects of non-verbal behaviour, such as dress or gesture can clearly contribute to the construction of identities, it is primarily through 'talk' that we establish mutual understandings of the import for identities of such non-verbal behaviours.

${ }^{3}$ Widdicombe (1998) also argues for an analysis of identity that is not only grounded in participant understandings but also theoretically-motivated, although her analysis is grounded in membership categorisation analysis.
} 
relationships with others), and communal (identities that emerge from groups and networks) (Hecht et al., 2005, pp. 263-264). The enactment of identities in communication involves both 'projecting' and 'attributing' particular identity claims by participants through verbal as well as non-verbal behaviours. This approach thus attempts to integrate 'macro-' and 'micro-level' perspectives on identity in order to bridge the gap between conversation analytic approaches to identity that orient exclusively to the 'local context' (cf. Schegloff, 1997), and critical discourse analytic approaches which draw from a broader notion of context (cf. Billig, 1999). In regards to the macro-level, the CTI focuses on how "what institution or institutions, or which group or groups of people, work to construct a given Discourse" (Gee, 2000-2001, p. 111), thereby giving rise to the 'echoing' of prior utterances of self and others, or what Bakhtin termed 'heteroglossia' (Gee, 2004, p. 300; Kramsch, 2002, p. 133). At the micro-level, the CTI explicates "how and by whom a particular identity is to be recognized" in interaction (Gee, 2000-2001, p. 109).

For example, when the present author was an international student at a university in Japan, he vacillated between projecting an identity as a learner of Japanese, which foregrounded his status as an international student, and projecting one as a user of Japanese, which backgrounded this status. In certain situations, he could discursively construct an identity as a learner of Japanese by asking for clarification about the meaning of a particular word when conversing with other students who were native speakers of Japanese (enacted identity), thereby positioning the other Japanese interactants as 'experts' and the author as a 'non-expert' international student dependent on those local students' expertise (relational identity). On the other hand, the author sometimes preferred to project an identity as a user of Japanese (personal identity), and attempted to discursively accomplish this by avoiding self-correction of errors, or by using various strategies to mask communication breakdowns (enacted identity). While some local students supported the author's attempts to project an identity as a user of Japanese by assisting in this masking of communication breakdowns and avoidance of explicit error correction, others would not, leading to discursive dispute about their respective roles (relational identity). In conversations with other students, the author also sometimes collectively identified with 'we' international students (communal identity) when other international students joined those conversations (enacted identity). He could also position himself as being somehow 'closer' to others in the group who also positioned themselves as international students rather than those who identified themselves as local students (relational identity). In this approach, then, it is assumed that these four dialecticallyinterpenetrating loci of identity are formed, maintained and modified primarily through discourse.

However, while the communication theory of identity assumes that identities are both enacted in, and constitutive of, communication, it focuses primarily on the interactional achievement of identities through talk-in-interaction, as well as the discursive disputes that can arise from gaps between projected (or expressed) and attributed identities in social interactions. In order to better understand how identities arise, then, it is important to add another layer to this analysis, namely how identities are not only constructed through discourse, but can also be discursively negotiated through social interaction. The discursive negotiation of the identities of participants in interviews or focus groups is characterized, in particular, by the property of emergence, as identity claims made by participants may not only be ratified or qualified by others (or themselves), but also challenged. Moreover, since interviews or focus groups, like other forms of discourse, involve participants mutually affording 
and constraining the meaning(s) of other participants (Arundale, 1999, p. 126), the identities which arise in such settings should be characterized as jointly constructed by participants. This means that what a certain participant says cannot be taken at face value, but must instead be carefully examined in relation to what other participants say (in order to establish the procedural relevance of the analysis), as well as relative to the researcher's own particular theoretical stance on identity.

While the notion of identity is treated in various ways across disciplines, it is suggested here that an interactional approach which conceptualizes identity as an emergent phenomena both enacted in, and constitutive of, communication can bring considerable insight into the analysis of the various ways in which the identities of international students are jointly constructed through discourse, including those arising in research interviews and focus groups.

\section{The Discursive Negotiation of International Student Identities}

In the following section, the CTI is applied to the analysis of data gathered from focus group interviews with international students. This data was collected over a period of six months using focus groups encompassing a total of 21 undergraduate students from a variety of countries, including Korea, China, Taiwan, Japan, Thailand, Russia and Chile. Each focus group involved two to four students, where the interviewer followed a semi-structured interview format in asking about the student's experiences at a particular university in Australia. ${ }^{4}$ While a diverse range of issues were raised by the students, ranging from the challenges they face in enrolling in a different institution to their interactions with local students, the focus in the following analysis is on the way in which the interpenetrating loci of their identities were discursively negotiated, and thus emerged, through discussion in these focus groups. The analysis thus concentrates on how identity claims are projected or attributed by participants (including the interviewer) in the focus groups, as well as being ratified, qualified or disputed by participants. Echoing the findings of Schuck (2006, p. 263) in her analysis of the discursive construction of 'nonnativeness' by Anglo-Americans, the identities in the following extracts were enacted through a number of strategies including: (1) marking of reference to ethnicity or nationality, (2) marking of the 'other' through pronouns and the like, and (3) alluding to intertextual relationships with broader, institutional (primarily media) discourses on international student identities.

\section{Discursive ratification}

Discursive ratification of the various identities enacted by one Japanese student is evident in the following extract from a focus group involving four international students from Japan, Korea and Russia. In this example, J1 represents the Japanese student, K1 a Korean student, and L the discussion facilitator. The following extracts are all transcribed using the standard Jefferson transcription system (Fitch \& Sanders, 2005, pp. xi-xiii), which is briefly outlined in the appendix that follows.

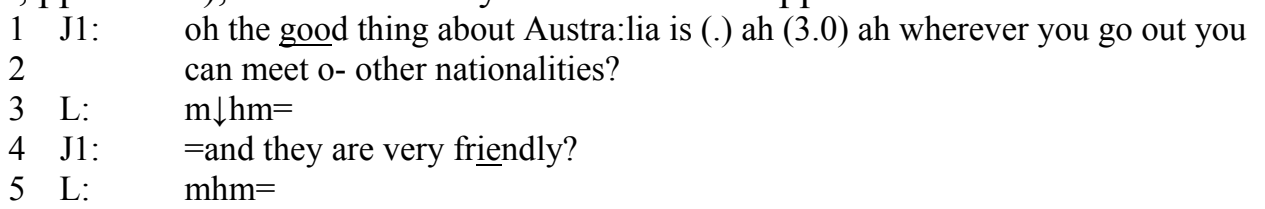

\footnotetext{
${ }^{4}$ These interviews were carried out by the author's research assistant, [omitted], and the author himself The author would like to thank both [omitted] for his assistance, and the Faculty of Arts at [omitted] University for providing funds for this project, which was part of a wider initiative aimed at providing assistance to international students entering the university.
} 


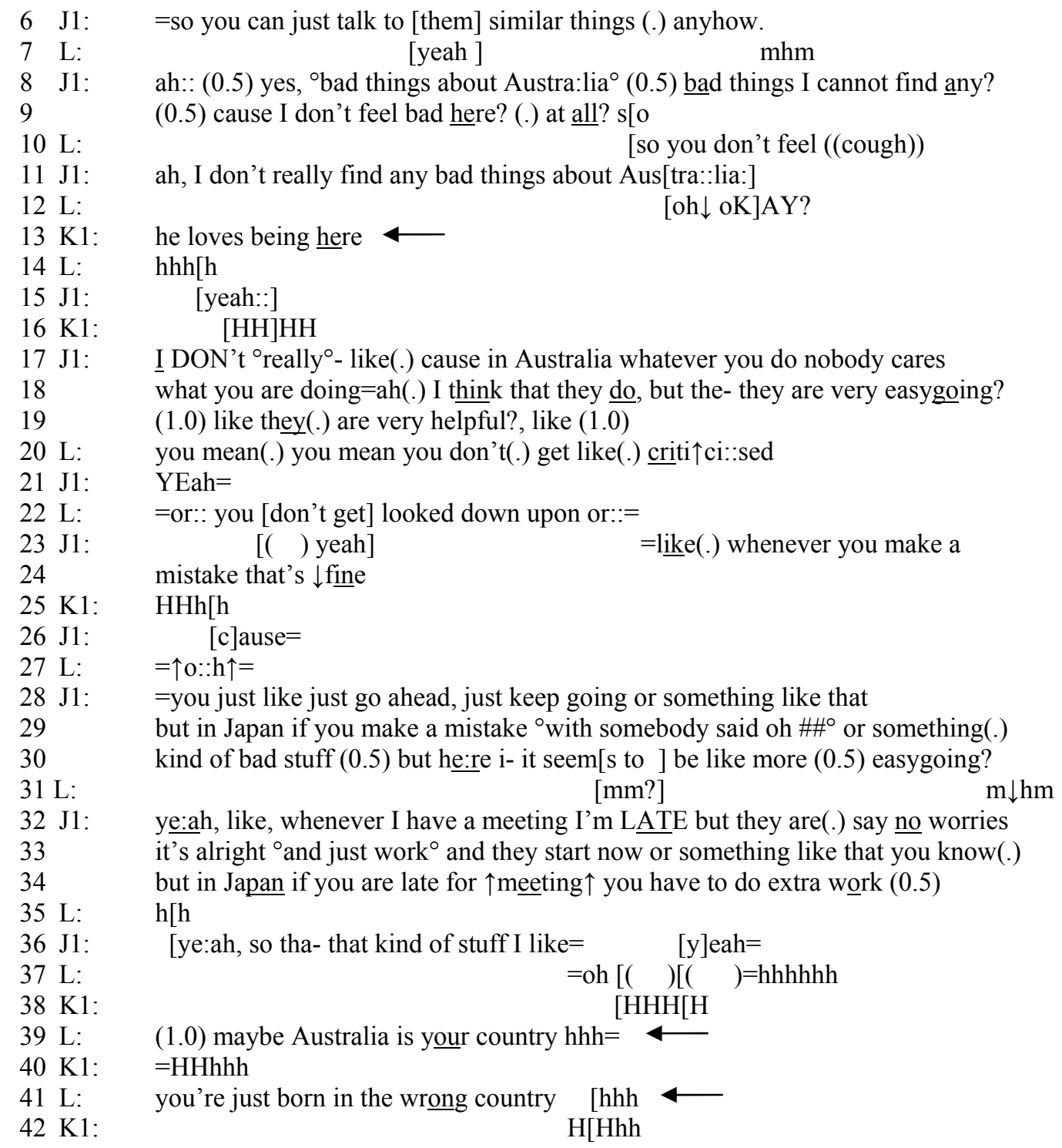

In this extract, the Japanese international student appears to enact a personal identity where he feels "at home" in Australia in lines 1-11. This positioning by J1 also has potential distancing implications for his communal identity as a member of Japanese society. This claimed personal identity is then endorsed by another Korean student participating in the focus group in line 13, and the endorsement subsequently accepted by $\mathrm{J} 1$ in line 15 , leading into further development of this theme by the Japanese student in lines 17-35. The focus group facilitator expands upon J1's remark in line 18 that Australians "are very easy going" in suggesting that Australians (who are positioned with an easy-going communal identity by both $\mathrm{J} 1$ and L) do not look down upon $\mathrm{J} 1$ in lines $20-22$. This is developed further by $\mathrm{J} 1$ in lines $23-24$ and $28-36$ where he relates his experiences in meeting local students for group assignments. J1's personal identity as a student "at home" in Australia is once again ratified by L in lines 39-41 where he jokingly suggests J1 was born in the wrong country. While the laughter from Louie and other participants at this point in the interaction is indicative of their understanding that this suggestion was not meant to be taken literally as characterising J1's personal identity as an "Australian," it does suggest a positioning of J1 by the facilitator and other participants as being closer to perceived 'easy-going' Australian values than some other international students. In this extract, then, while J1 certainly is the driving force behind the enactment of these particular personal (and 
communal) identities, they are discursively accomplished through not only his remarks, but also through the encouragement and support given by other participants in this focus group for these projected identities. These identities are ratified by other participants, and thus jointly constructed by all the participants, including the interviewer.

Discursive ratification of a relational identity where international students are positioned as outsiders in interactions with local students was apparent in the following extract from another focus group involving three international students from Taiwan (T1-3), as well as the author (M).

1 T1: but I THInk (0.2) sometimes(.) Australia it's hard to, you know, deal with (0.5)

2 the relationship [between] =yeah $\downarrow$ international and $(0.5) \downarrow$ local ${ }^{\circ}$ people ${ }^{\circ}=$

$3 \mathrm{M}: \quad[\mathrm{o}: \mathrm{h} \mathrm{o} \downarrow \mathrm{k}] \mathrm{ay}=$

4 M: $\quad=0:: h$ ok $\downarrow$ ay, so what do you find difficult ${ }^{\circ}$ in in doing that ${ }^{\circ}$ ?=

5 T1: =maybe(.) when I- when I- I'm doing my project?

6 M: $\quad$ ye $\downarrow$ ah

7 T1: $\quad$ sometimes you have to discuss with $\downarrow$ them but they are not so concentrate on $\downarrow$ YOU

8 M: $\quad \downarrow \mathrm{mm}$

9 T1: or even I take this class like ((course name))?

$10 \mathrm{M}: \quad \mathrm{mm}$

11 T1: and then(.) when I'm nervous on- (0.5) a::h when I'm (0.5) giving the discussion

with my friends

$14 \mathrm{~T} 1: \quad=$ but they just sometimes just $\uparrow o:: \mathrm{h}$ a::h yeah $\uparrow{ }^{\circ} \mathrm{uhm}^{\circ}(0.5)$ ignore you

$15 \mathrm{M}: \quad$ o::h o:kay

16 T1: most- most of them ${ }^{\circ}$ like that ${ }^{\circ}$

[section omitted]

17 T3: I didn't really have good experience [in working] (.) wo:rk ${ }^{\circ}$ ing with $^{\circ}$ (.)

$18 \mathrm{M}$ :

19 T3: [o::h o:kay]

$20 \mathrm{M}$ :

$21 \mathrm{~T} 3$ :

Aussie students $\mathrm{mm}(.) \mathrm{mm}(.) \mathrm{mm}$

(1.0) u:::hm I think- I don't know maybe they just think I'm DUMb or something $>$ I dunno $<$, when I $(0.5)$ express my o-hh opinions to people I saw they don’t listen, ${ }^{\circ} \mathrm{o}: \mathrm{h}$ o $\downarrow \mathrm{kay}^{\circ}$ ((looking at T1)) [like just wh] at you said

34 T3:

35 T2:

$36 \mathrm{~T} 1$ :

37 T3:

just ignore you $=$

[a:nd [ye:ah ye:ah]

$$
\begin{aligned}
=\downarrow \mathrm{ah} & = \\
& ={ }^{\circ} \mathrm{mm} \text { oh }[\text { okay }]^{\circ}
\end{aligned}
$$

$\downarrow$ yeah (1.0) and (1.0) whatever you've done you han- yo- you take it to your friends, and they(.) say okay can I have your- okay we can work together, and you- when you receive like the result of the $=$

$=\mathrm{mm}$

the homework, and you find out (0.5) your one(.) hh is nOT there=

$=\mathrm{YE} \downarrow \mathrm{ah}$

hhh [not there, and I JUST felt(.) [very disappointed, and it- okay= [HHhhhh

$=$ so we do it and[HHHhhhhhhhhh

that's okay if you found that my work is not(.) good as you expected that's fine but you have to communi[cate with] me but I didn't know anything about it=

so, I just feel very ${ }^{\circ}$ disappointed $^{\circ}$

$$
[\mathrm{m}: \mathrm{m} \mathrm{mm}] \quad=\mathrm{mm}
$$

In this focus group, two of the Taiwanese students enact relational identities where they feel their opinions are not valued by 'local students', and consequently also potentially enact communal identities involving shared negative experiences with 'local students'. These relational identities are first enacted by T1 in lines 1-16, and then later in the discussion are endorsed by the two other students in relating their own negative experiences with local students where they felt undervalued. T3, in particular, relates her own negative experiences with 'local students' in lines 17-40. 
T3's experiences are strongly endorsed by both T1 (lines 24, 36) and T2 (line 33), evident from their emphatic insertions into T3's narrative. Thus, while T1 and T3 describe their negative experiences with local students with first-person pronouns, the emphatic mutual endorsement by all three students indicates such experiences are shared, and so contribute to the emergence of a broader communal identity encompassing how 'international students' are treated by 'local students'. The local students themselves are all positioned as 'the other' (for example, through the labelling of groups by $\mathrm{T} 1$ in line 2), with their communal identity being enacted as lacking in respect towards these international students. This positioning by these students also 'echoes' broader community perceptions of international students constructed through media discourse as being somehow less capable than 'local students', and this suggests that, potentially at least, these students may be aware at some level of this broader discourse.

\section{Discursive qualification}

The enacted identities of students were also discursively qualified by other students, as evident in the following extract taken from a focus group involving three students from Japan and Korea. In this example, J2 represents another Japanese student, while K2 another represents a Korean student.

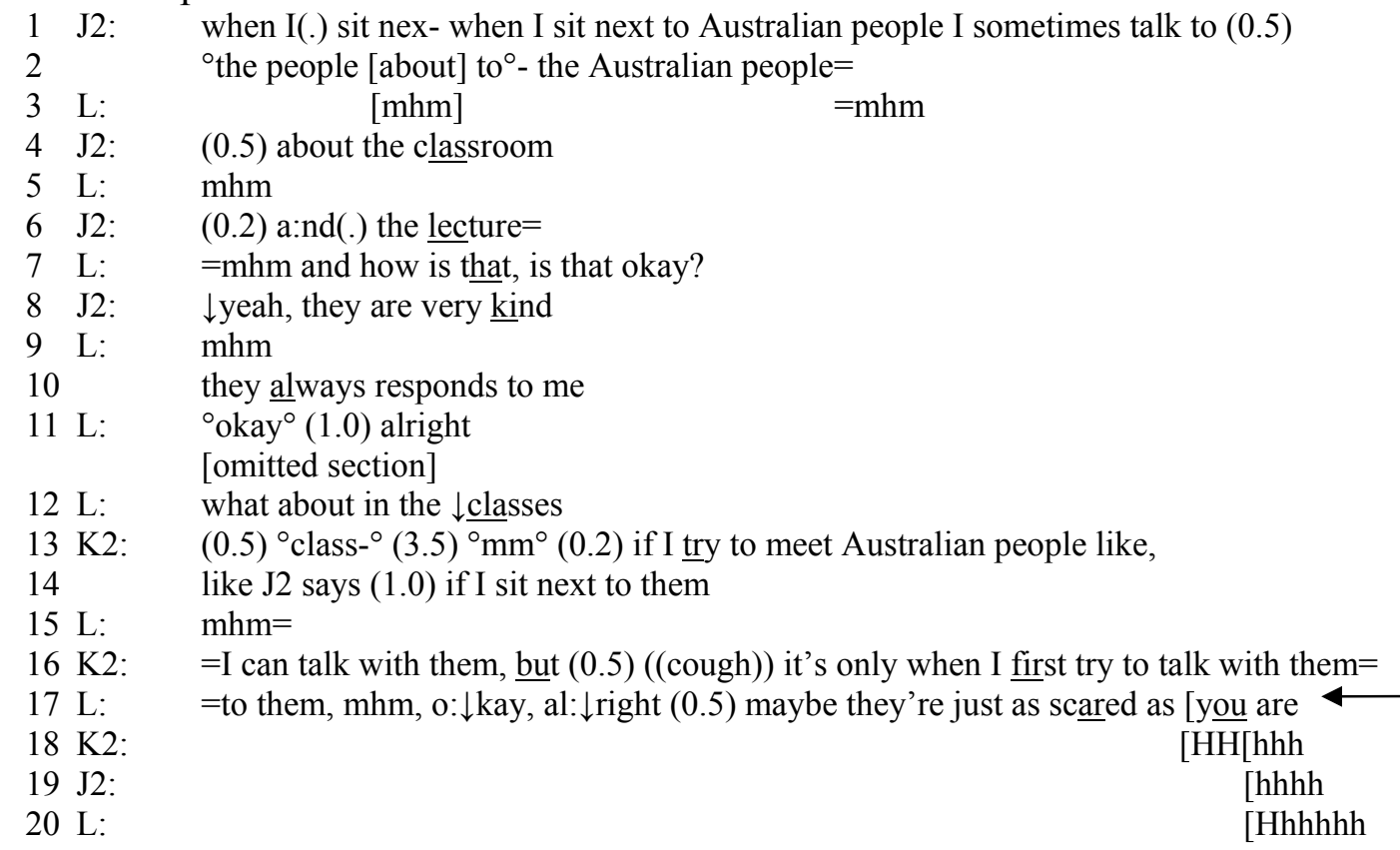

In this extract, the international students in this group enact a positive relational identity with local students when questioned about their interactions with local students by the interviewer. While the Japanese student claims local students always talk to her in lines 8-10, this experience, which has potential implications for her relational identity (i.e., where international and local students are friendly towards each other), is explicitly qualified by the Korean student who claims in line 16 that local students only talk to her when she initiates the conversation, something which is only implied by the $\mathrm{J} 2$ in line 10 ("they always responds to me"). The interviewer then suggests local students may be just as nervous as them in line 17, building on comments the participants had previously made about feeling nervous when interacting with local students. He thus accepts the positioning by these students of local students as being friendly, but perhaps somewhat limited by mutual nervousness about crossing implicit 'boundaries' in their relationships. This qualification of the 
local students behaviour, and thus positioning of them as nervous about talking with international students rather than being unfriendly by L, appears to be endorsed by the participants by the laughter that follows his comment in lines $18-20 .^{5}$ In this way, this positioning and thus relational identity emerges from the contributions of all the participants in this extract.

\section{Discursive dispute}

However, it was not always the case that the identities projected by participants in the focus groups were endorsed by other participants. In the next example, discursive dispute over the relational identities of these international students arose in a focus group involving four international students. In this extract, K3 represents a Korean student, R represents a Russian student, and J3 represents another Japanese student in that group.

1 K3: I- yeah, especially me, $\mathrm{mm}$ my experience is very short a:nd=

$2 \mathrm{~L}: \quad=\mathrm{mhm}$

3 K3: my English is very bad, so I wanna help- hh I wanna (0.3) help somebody to

4 im- improve my English? or- (1.0) there is no- no advice for me and (1.0) a:h so (1.0)

5 well a:h, so I wanna ask (0.5) teachers, or professors, or the tutorial teachers, but they

6 said just like(.) go to institution, eh, institute, TAFE, ( ) TAFE or ((omitted)) Institute

$7 \mathrm{~L}: \quad \mathrm{mhm}$

8 K3: th- they just said, and (.) they don't concern about my situation?

$9 \quad$ a:nd (1.0) another thing i:s (.)

$10 \mathrm{~L}: \quad$ so $\downarrow$ rry can you tell me more about that? what do you mean they say go to-

11 go [to

$12 \mathrm{~K} 3$ : [go to institute, just sort of TAPE and (1.0) TAPE, TAFE

$13 \mathrm{R}: \quad \mathrm{TA}[\mathrm{FE}$ ?]

$14 \mathrm{~K} 3$ :

$15 \mathrm{~L}:$

$16 \mathrm{~K} 3$ :

[insti] tute, yeah TAFE institute, or ((omitted)) Institute, of (.) English, yeah

but you are at university $\downarrow$ now

(1.5) ye:ah

(0.5) o:: $\downarrow$ kay $(1.0)$

$18 \mathrm{R}: \quad$ can $\mathrm{I}^{\circ} \mathrm{add}^{\circ}$ just a little bit?

$19 \mathrm{~L}: \quad$ ye:ah $\downarrow$ sure

$20 \mathrm{R}: \quad$ I think u:hm, why they like that, and I think $\mathrm{L}$ just kind of a:Imost answered

21 the question because when you are at the university you already passed the

22 test, and(.) you're already expected to have certain level of English=

$23 \mathrm{~J} 3:=$ yeah yeah yeah

$24 \mathrm{R}$ : $\quad$ and for them to actually, you know, sit down and kind of supervise you on

25

English- people here don't do that

In this extract, the Korean student positions herself in lines 1-9 as not getting the level of service in relation to improving her English as she expects, thereby enacting a relational identity for herself as an unsatisfied customer in regards to an institution she positions as being indifferent towards the problems she faces. However, this particular relational identity is not ratified by either the interviewer or the other participants. The interviewer implies in line 15 that she is expected to manage her own learning at universities in Australia, in response to which $\mathrm{K} 3$ first pauses and then displays uncertainty through the flat pitch of "yeah" in line 16. This implicature is made more explicit by the Russian student in lines 18-22, when she states that international students are expected to have a certain level of English before entering the university, and thus K3 cannot expect such extensive help with her English. This opposing position is endorsed by another Japanese student in line 23, before $\mathrm{R}$ goes on to imply

\footnotetext{
${ }^{5}$ The identities arising in this extract thus contrast with those found in the previous extract. This was not an uncommon occurrence across these focus groups, where the multiple experiences and identities that arose were often found to be contradictory.
} 
in lines 24-25 that the Korean student's expectations are not reasonable. There was no evidence in the latter part of the discussion, however, that this Korean student accepted this alternative attributed personal identity (as a student who is unaware of what is expected of her). This extract thus highlighted discursive dispute about the identity of this particular student, between K3's positioning of herself as a victim of poor service, and others' positioning of her as being unaware of the expectations of the institution in regards to her level of English. Thus, the view that identities are jointly constructed or negotiated through discourse does not amount to a claim that participants will always reach agreement about the discursive enactment of their identities. It is also notable that by disputing K3's claim she was unfairly treated, the other participants are 'echoing' broader community expectations constructed through media discourse and the like that international students should reach an adequate level of English before entering Australian universities.

\title{
Concluding remarks
}

The ways in which the identities of international students are constructed through discourse has received considerable attention in the literature thus far. Most studies have relied upon qualitative research methodologies, such as one-to-one interviews or focus groups with international students themselves or other groups, to examine the kinds of identities that are projected by, or attributed to, international students. However, in many of these studies, the interviewer's contribution to the talk as well as other participants, when present, has been framed as neutral in relation to the construction of international student identities in discourse. In other words, they have remained epistemologically "ambigious between process and product, between the way one gets there, and the result" (Hacking, 1999, p. 36). Yet the current analysis indicates that the interviewer's attributions of identities as well as those of others are part of this process, and indeed cannot be easily separated from the students' own projection of their identities, as identities are ultimately discursively enacted and negotiated through social interaction. This finding indicates that we need to treat interview or focus group data not as texts from which one can "read off" an analysis, but rather as interactional data, in which the ways meaning(s) are jointly constructed through discourse must be carefully analysed by the researcher.

This should not lead us, however, to the erroneous conclusion that qualitative methodologies are inherently subjective or flawed, but instead to acknowledge that

all knowledge, and therefore all meaningful reality as such, is contingent upon human practices, being constructed in and out of interaction between human beings and their world, and developed and transmitted within an essentially social context. (Crotty, 1998, p. 42)

In this way we can further our understanding of how identities are not social phenomena that simply need to be "discovered" by researchers, but rather are jointly constructed through discourse. Such a perspective, however, requires an increased awareness of how the researcher's perspectives are inevitably involved in discursively negotiating identities. In doing so, it is also important to note that the enactment of identities in research interviews is constrained by broader institutional norms of conducting interviews, where turn-taking rights, for example, are asymmetrical (Heritage, 2005). Thus, analyses of identities in other forms of talk-in-interaction needs to complement work on individual or focus group interviews.

\section{Appendix: Transcription conventions}

\author{
CAPITALS higher pitch volume \\ o markedly soft speech
}




$\begin{array}{ll}\text { underlining } & \text { stressed word or part of word } \\ \uparrow \downarrow & \text { marked rises or falls in pitch } \\ \text { hhh } & \text { hearable aspiration or laugh particles } \\ {[]} & \text { overlapping talk } \\ = & \text { talk 'latched' onto previous speaker's talk } \\ : & \text { stretching of sound of preceding letter } \\ (.) & \text { micro-pause } \\ (0.2) & \text { timed pause } \\ - & \text { cut-off of prior sound in a word } \\ ( & \text { blank space between brackets indicates unintelligible speech } \\ ((\text { cough })) & \text { transcriber's description of non-verbal activity }\end{array}$

\section{References}

Antaki, C., \& Widdicombe, S. (1998). Identity as an achievement and as a tool. In C. Antaki \& S. Widdicombe (Eds.), Identities in talk (pp.1-14). London: Sage.

Antaki, C., Condor, S., \& Levine, M. (1996). Social identities in talk: speakers' own orientations. British Journal of Social Psychology 35, 473-492.

Arundale, R. (1999). An alternative model and ideology of communication for an alternative to politeness theory. Pragmatics, 9(1), 119-154.

Barbour, R., \& Kitzinger, J. (Eds.). (1999). Developing focus group research. Politics, theory and practice. London: Sage.

Benwell, B., \& Stokoe, E. (2006). Discourse and identity. Edinburgh: Edinburgh University Press.

Billig, M. (1999). Whose terms? Whose ordinariness? Discourse and Society 10(4), 543-558.

Berger, P., \& Luckmann, T. (1966). The social construction of reality. NY: Doubleday.

Crotty, M. (1998). The foundations of social research. St Leonards, NSW: Allen \& Unwin.

Curnow, S. (producer). (2005, 27 June). The degree factories [Television broadcast]. Sydney: Australian Broadcasting Corporation.

Daglish, C., \& Chan, A. (2005). Expectations and reality. International students reflections on studying in Australia. Paper presented at the AIEC Conference, Gold Coast. Retrieved 7 July, 2006, from http://www.idp.com/aiec/pastpapers/article17.asp.

De Fina, A., Schiffrin, D., \& Bamberg, M. (2006). Introduction. In A. De Fina, D. Schiffrin \& M. Bamberg (Eds.), Discourse and identity (pp.1-23). Cambridge: Cambridge University Press.

Devos, A. (2003). Academic standards, internationalisation, and the discursive construction of "the international student". Higher Education Research and Development, 22(2), 155-166.

Drew, P. (2005). Conversation analysis. In K. Fitch \& R. Sanders (Eds.), Handbook of language and social interaction (pp.71-102). Mahwah, NJ: Lawrence Erlbaum.

East, J. (2001). International students identified as customers: their expectations and perceptions. Paper presented at the Changing Identities. Language and Academic Skills Conference, University of Wollongong. Retrieved 16 June, 2006, from http://learning.uow.edu.au/LAS2001/index.htm.

Fitch, K., \& Sanders, R. (2005). Handbook of language and social interaction. Mahwah, NJ: Lawrence Erlbaum.

Foucault, M. (1979). Discipline and punish. London: Penguin.

Gee, J. P. (2000-2001). Identity as an analytic lens for research in education. Review of Research in Education 25, 99-125.

Gee, J. P. (2004). New times and new literacies. In A. Ball \& S. Warschauer Freedman (Eds.), Bakhtinian perspectives on language, literacy and learning (pp.279-306). Cambridge: Cambridge University Press.

Hacking, I. (1999). The social construction of what? Cambridge, Massachusetts: Harvard University Press.

Hart, C., \& Edwards, V. (2007, 30 January). More uni English woes tipped. The Australian, p.2.

Hecht, M. (1993). A research odyssey: towards the development of a communication theory of identity. Communication Monographs, 60(1), 76-82.

Hecht, M., Warren, J., Jung, E., \& Krieger, J. (2005). The communication theory of identity. In W. Gudykunst (Ed.), Theorizing about intercultural communication (pp. 257-278). Thousand Oaks, CA: Sage.

Heritage, J. (2005). Conversation analysis and institutional talk. In K. Fitch \& R. Sanders (Eds.), Handbook of language and social interaction (pp.103-147). Mahwah, NJ: Lawrence Erlbaum. 
Hills, R. (2005, 3 June). No time to learn for learning's sake when a degree is at stake. The Sydney Morning Herald, p. 13.

Ho, D. (2006). The focus group interview. Rising to the challenge in qualitative research methodology. Australian Review of Applied Linguistics, 29(1), 5.1-5.19.

Ingram, D. (2005, 2 July). English language problems in Australian universities, Lingua Franca. Sydney: Radio National.

Johnson, G. (2006). The discursive construction of teacher identities in a research interview. In A. De Fina, D. Schiffrin \& M. Bamberg (Eds.), Discourse and identity (pp.213-232). Cambridge: Cambridge University Press.

Jopson, D., \& Burke, K. (2005, 7 May). Campus critical. The Sydney Morning Herald, p. 27.

Jung, E., \& Hecht, M. (2004). Elaborating the communication theory of identity: identity gaps and communication outcomes. Communication Quarterly, 52(3), 265-283.

Kitzinger, J. (1994). The methodology of focus groups: the importance of interaction between research participants. Sociology of Health \& Illness 16(1), 103-121.

Koehne, N. (2005). (Re)construction: ways international students talk about their identity. Australian Journal of Education, 49(1), 104-119.

Koehne, N. (2006). (Be)Coming, (Be)Longing: Ways in which international students talk about themselves. Discourse: Studies in the Cultural Politics of Education, 27(2), 241-257.

Kramsch, C. (2003). Identity, role and voice in cross-cultural (mis)communication. In J. House, G. Kasper \& S. Ross (Eds.), Misunderstandings in social life (pp.129-153). London: Longman.

Leder, G., \& Forgasz, H. (2004). Australian and international mature students: the daily challenges. Higher Education Research and Development, 23(2), 183-198.

Macnamara, L. (2006, 24 June). English all Dutch to foreign students. The Australian, p.7.

Macnamara, L. (2007, 28 March). Soft on foreign students. The Australian, p.34.

Miller, J. (2000). Language use, identity, and social interaction: migrant students in Australia. Research on Language and Social Interaction, 33(1), 69-100.

Miller, J., \& Glassner, B. (2004). The "inside" and the "outside". Finding realities in interviews. In D. Silverman (Ed.), Qualitative research. Theory, method and practice ( $2^{\text {nd }}$ edn) (pp.125-139). London: Sage.

Morgan, D. (1996). Focus groups. Annual Review of Sociology, 22, 129-152.

Morgan, D. (1997). Focus groups as qualitative research (2nd ed.). Thousand Oaks, CA: Sage.

Morita, N. (2004). Negotiating participation and identity in second language academic communities. TESOL Quarterly, 38(4), 573-603.

Morris, S. (2004, 31 July). Dumb dumber \&. Australian Financial Review, p. 17.

Schegloff, E. (1991). Reflections on talk and social structure. In D. Boden, \& D. Zimmerman (Eds.), Talk and social structure: studies in ethnomethodology and conversation analysis (pp. 44-70). Cambridge: Polity Press.

Schegloff, E. (1992). In another context. In A. Duranti \& C. Goodwin (Eds.), Rethinking context: language as an interactive phenomenon (pp.193-227). Cambridge: Cambridge University Press.

Schegloff, E. (1996). Issues of relevance for discourse analysis: contingency in action, interaction and co-participant structure. In E. Hovy \& D. Scott (Eds.), Computation and conversational discourse: burning issues - an interdisciplinary account (pp.3-38). Heidelberg: Springer.

Schegloff, E. (1997). Whose text? Whose context? Discourse and Society 8(2), 165-187.

Sherry, C., Bhat, R., Beaver, B., \& Ling, A. (2004). Students' as customers: the expectations and perceptions of local and international students. Paper presented at the HERDSA 2004 Conference, Curtin University of Technology, Sarawak, Malaysia. Retrieved 16 June, 2006, from http://www.herdsa.org.au/conference2004/Contributions/RefereedPapers.htm.

Shuck, G. (2006). Racializing the nonnative English speaker. Journal of Language, Identity, and Education 5(4), 259-276.

Simon, B. (2004). Identity in Modern Society. A Social Psychological Perspective. Oxford: Blackwell.

Weedon, C. (1987). Feminist Practice and Poststructuralist Theory. London: Blackwell.

Widdicombe, S. (1998). Identity as an analysts' and a participants' resource. In C. Antaki \& S. Widdicombe (Eds.), Identities in talk (pp.191-206). London: Sage.

Wilkinson, S. (2004). Focus group research. In D. Silverman (Ed.), Qualitative research. Theory, method and practice ( $2^{\text {nd }}$ edn) (pp.177-199). London: Sage. 